\title{
THE IMPROVEMENT OF DYNAMIC COMMUNICATIONS IN A COMPLEMENTARY SYSTEM FOR MANAGING THE DEVELOPMENT OF SELF-GOVERNING TERRITORIES
}

\author{
Oleh Buzun ${ }^{1}$
}

\begin{abstract}
The purpose of the article is to substantiate approaches to the principles of improving dynamic communication in a complementary system of development management of self-governing territory (SGT). Problem statement (the description of the problem being analyzed in general and its relevance to important scientific or practical tasks). At the present stage of socio-economic and decentralization reforms in Ukraine, the formation of the effective development models of all SGTs (on regional, sub-regional and local levels) becomes a strategic and priority task of all institutions of power. At the same time, the issues of optimization of the complementary management system for the development of SGTs have not yet been the subject of special research, which necessitates the preparation of this publication. The methodological principles of the complex mechanism of the formation of a new model of SGTs development are offered on the basis of providing cooperation in the processes of integrated development. It is stated that our model of SGT is a coherent system, which correlates governance at the state, regional, sub-regional and local levels through different types of connections. The content of each type of connection at different levels of public administration is revealed. The results of the research prove that the effective functioning of the proposed model is possible under the condition of management relations improvement; the observance of the development process properties and the coordination of the subjects of influence in the process of prospect formation of the SGT. Practical implications are that co-operation and an integrated approach in the development of SGTs in Ukraine will allow to save industrial and social infrastructure, to prevent outflow of highly qualified personnel from the communities, will provide comprehensive support to the domestic producer and social protection of the population. Co-operation is able to provide an impetus for the development of small businesses and enterprises, and to improve the well-being of the individual family and the entire community in general. The research has its value and originality. It is that SGTs should be dominant in the Ukrainian reform. The issue of scientific and methodological substantiation and building of an effective system of development of self-governing communities on the basis of solving the problematic issues of modernization acceleration, the activation of innovations, the ensuring of cooperation and the integrated development is extremely urgent and determines the priority for improvement of the current management system.
\end{abstract}

Key words: self-governing territories(SGTs), local self-government, regional policy, territorial communities, the system for managing the development.

JEL Classification: H70, R10, R50

\section{Introduction}

The presentation of the main research material with full justification of the obtained scientific results. The model of SGTs development reflects the state, regional, sub-regional and local levels of government. The processes of decentralization in our country are gradually shifting managerial emphasis and the authority powers towards regional, sub-regional and local levels, where a new philosophy requires the functioning of public authorities, the formation of a national model of local self-government, the subject of which is a selfgoverning community. In the process of reforming, the establishing and further development of selfgoverning territories, various types of links of self-governing territorial-administrative units are being adjusted and subsequently improved as well as different types of connections of self-governing territorial and administrative units become better (Figure 1). 


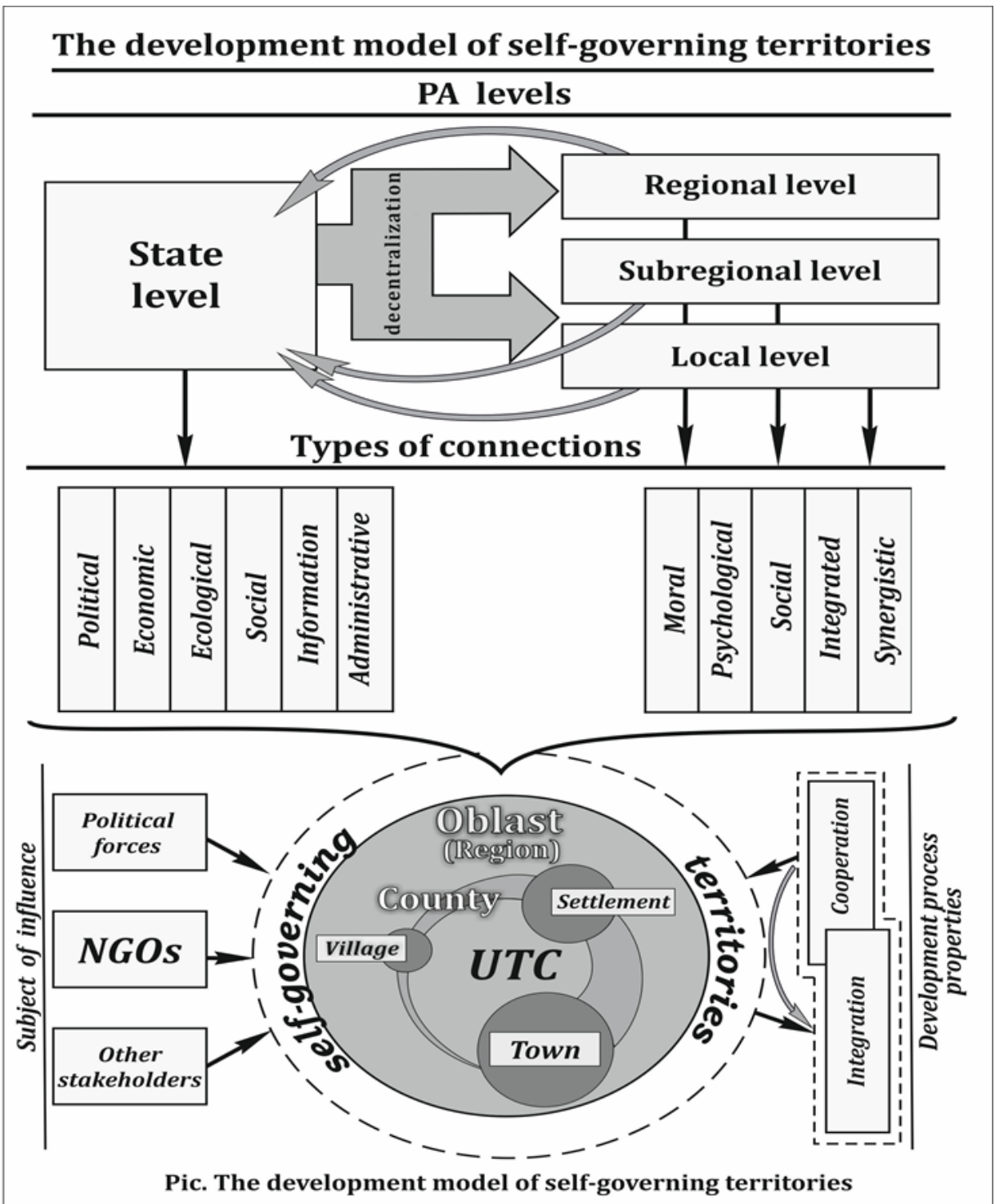

Figure 1. The development model of self-governing territories

Source: developed by the author

PA levels - public administration levels;

UTC - united (amalgamated) territorial community;

NGOs - non-governmental organizations.

Political connections (PCs) of self-governing territories (SGTs) with the state administrative level are the process of legislative support, establishing and formation of self-governing communities and their management in the interests of the state political system and its local administrative and self-governing components. PCs between the SGTs and the state aimed at respecting self-governing rights should find their confirmation in the specific state policy, functions, forms, methods and mechanisms of public administration, and not be merely a declarative norm of the current legislation of Ukraine.
Based on the Declaration on State Sovereignty of Ukraine, on December 7, 1990, the Law of the USSR "On Local Councils of People's Deputies of the Ukrainian SSR and Local Self-Government" was adopted. The adoption of the Constitution of Ukraine in 1996 was the beginning of the new stage of development of society and set the task of building a democratic, sovereign, rule of law.

The next major step in our state policy was the adoption of the laws of Ukraine governing the principles of local self-government, the powers of bodies and officials of the local self-government: 
"On Local Self-Government in Ukraine" in 1997; "On Service in Local Self-Government Bodies" in 2001; "On Self-Organization Bodies in Population" in 2001; "On the Status of Deputies of Local Councils" in 2002. To this list, the Law of Ukraine "On Local State Administrations" 1999 is added, which exercises the powers delegated by the respective councils.

During the same period, Ukraine coordinates its conceptual foundations for the construction and functioning of the local self-government system with international acts, in particular: the World Declaration on Local Self-Government dated 1985 (Pohorilko, 2001) and the European Charter on Local Self-Government dated 1985 (Official Bulletin of Ukraine, 2015). It should be noted that the European Charter on Local SelfGovernment, which is formally a part of Ukrainian legislation today, should be directly applied in real life and correct the legal inconsistencies that should be settled in the near future by domestic parliamentarians. The Decentralization reform, launched in Ukraine in 2014, was aimed at improving public administration, as a necessary prerequisite for getting out of the political crisis and developing SGTs. On December 28, 2014, the Verkhovna Rada of Ukraine approved amendments to the Tax and Budget Codes of Ukraine that defined the new financial framework of local selfgovernment bodies, established a new distribution of national taxes and introduced new local taxes, and introduced a new system of budgetary equalization.

The following progress was made with the laws of Ukraine: "On cooperation of territorial communities" (No. 1508-VII dated June 17, 2014) and "On voluntary amalgamation of territorial communities" (No. 157-VIII dated February 5, 2015), the latter is the main document allowing to consolidate communities without amending the Constitution of Ukraine.

In 2015, the Cabinet of Ministers of Ukraine approved Resolution No. 214 "On Approving the Methodology of Forming Able Territorial Communities" and adopted the law "On Fundamentals of State Regional Policy”, which formed new principles for regional policy formation. On August 31, 2015, in the first reading, the Verkhovna Rada of Ukraine approved the Amendments to the Constitution on the Decentralization of Power, the State Regional Development Fund (SRDF) was also founded, and the budgets of newly created communities were given the opportunity to switch to direct relations with the state budget (International Alert, 2017).

Currently, the Ministry for Communities and Territories Development of Ukraine, in collaboration with the Ministry of Health, the Ministry of Education and Science, and other relevant ministries, forms boundaries and models community associations, taking into account the standards of accessibility and quality of administrative and social services. The outlined plans have already been sent to the regions. The functions of supervising and controlling the activities of local self-government bodies in the area of compliance with the lawful decisions of the legislation will have prefectures. In general, the merger process should be completed in 2020, according to the profile ministry opinion (Babak, 2019).

In order to achieve more concrete changes in the political linkages of the development of our proposed SGTs model, it is necessary to build a coherent concept of reforming local selfgovernment in modern Ukraine, which would include decision-making and promotion of ideas on optimal change of the existing organizational structure of self-governing territories based on the influence of political institutions.

\section{Economic relations (ER of SGTs)}

During 2014-2020, the local self-government reform has been underway in Ukraine, which is aimed at creating capable territorial communities. The newmergers enterinto directintergovernmental relations with the State Budget and receive new powers. The compliance with the principle of subsidiarity implies that the greatest powers are vested in those authorities which are closest to the people. Therefore, United (Amalgamated) Territorial Communities (UTCs) are given the authority related to community development planning and budgeting; stimulating economic development and attracting investment; land management; development of local infrastructure; provision of housing and communal services; organization of passenger transportation on the territory of the community; public safety and fire protection; provision of social and administrative services; primary care; education and culture.

By 2020, the following changes have already taken place in Ukraine to support the development of the SGTs:

1. Budgetary and financial autonomy of local budgets has increased. 
2. There has been created a mechanism to encourage communities to unite and form capable territorial communities through the transition of the budgets of the united communities to direct intergovernmental relations with the State Budget of Ukraine, giving such communities the powers of the cities of regional importance.

3. The revenue base of local budgets has been expanded by: fixing local sources with stable sources - tax on incomes of individuals according to new standards (budgets of cities of regional importance, districts - 60\%, regional budgets - $15 \%$, the budget of Kyiv - 40\%) and corporate income tax of the private sector (regional budgets - 10\%); since 2015, the introduction of the collection of retail sales of excisable goods (alcoholic beverages, tobacco, petroleum products) at a rate ranging from $2 \%$ to $5 \%$ (today, it is $13.44 \%$ ) of the value of goods sold; since 2015, the extension of the real estate tax base to include commercial (non-residential) property; transfers from the state budget of payment for the provision of administrative services (except $50 \%$ of the administrative fee for state registration of real rights to real estate and their encumbrances and state registration of legal entities and entrepreneurs), State Duty; the increase of percentage of environmental tax credit from 35 to $80 \%$.

4. New types of transfers have been introduced (basic grant, educational subvention, subvention for training of workers, medical subvention, subvention for provision of medical measures of separate state programs and complex measures of program character, reverse subsidy).

5. A new system of equalization for fixed national taxes (income tax and personal income tax) has been introduced, depending on the level of income per capita.

6. The responsibility of the profile ministries for implementing public policies in the education and medical sectors has been strengthened by identifying the relevant subventions as their main spending units.

7. The right to choose the institution (in the bodies of the Treasury or banks) on the maintenance of the budget funds of development of local budgets and own revenues of budgetary institutions has been granted.

8. The process of providing local guarantees and borrowing from international financial institutions has been simplified.
9. The delimitation of the environmental tax credit (except for the tax charged for the generation of radioactive waste) has been changed, with the assumption that $20 \%$ of revenues will be credited to the state budget, and $80 \%$ to local budgets, including to the regional budgets - 55\%, rural, settlement, city budgets $-25 \%$ and Kyiv city budget $-80 \%$.

In addition to these financial opportunities, in accordance with Article 241 of the Budget Code of Ukraine, the united (amalgamated) territorial communities (UTCs) got the possibility to apply to the State Regional Development Fund for funding their own regional development investment projects (Bryl, Vrublevsky, Dancheva, Seitosmanov, Chubarov, 2018).

The consolidated successes of financial and economic decentralization need to be further developed. The formation of the model of balanced development of self-governing territories should be aimed at the realization of long-term state goals that will facilitate the concentration of resources, increase the efficiency of production, the formation of a new branch structure, the development of new infrastructure projects that will affect better cooperation of self-governing communities and improve the quality of life at the local level and at the state level as a whole.

\section{Ecological links (ELs) of SGTs}

In Ukraine, the national environmental policy is outlined in the "Main directions of the state policy of Ukraine in the field of environmental protection, use of natural resources and ensuring environmental safety", approved by the decision of the Verkhovna Rada of Ukraine No. 188/98BP dated March 5, 1998. Domestic legislation declares the protection of environmental rights and participation of the SGTs and the public in making ecologically significant decisions: the Constitution of Ukraine (Article 50), the laws of Ukraine "On Environmental Protection" in 1991, "On the Nature Reserve Fund of Ukraine" in 1992, "On fauna" in 2001, the Subsoil Code of Ukraine, the Water Code of Ukraine, the Land Code of Ukraine, the Forest Code of Ukraine. etc.), and dozens of other pieces of legislation. In addition, the guarantees of public participation in resolving any issues are enshrined in the Law "On Local SelfGovernment in Ukraine" (Articles 7, 8, 9, 13) and in the Law "On All-Ukrainian Referendum". The current document specifically aimed at ensuring the environmental rights of citizens is "The 
Convention on Access to Information, Public Participation in Decision-Making and the Access to Justice in Environmental Matters," ratified by the Verkhovna Rada of Ukraine in May 1999. The Presidential Decree No. 287/2015 dated May 26, 2015 approved the new National Security Strategy of Ukraine (Andrienko, Shako, 2017). The strategic task of bringing ecological links to world standards is not only the preservation of the environment and the satisfaction of basic human needs: clean air, clean food; provision of land improvement; implementation of energy saving measures; provision of housing and communal services, such as water supply and sewerage; solid waste management and the like. These are the tasks that will have a positive impact on the environment in the future.

\section{Social Connections (SCs) of SGTs}

Prior to the decentralization processes, in the social sphere there was a significant decline in the economic development of rural areas, which in turn influenced the deterioration of social services and led to a decrease in the quality of life. Closures of RHCs (rural health centers), kindergartens, public service centers, and other social sites were commonplace. Children could not be provided with quality education in incomplete classes. The Houses of culture and libraries became more expensive to maintain for local budgets. Problems of transport between villages began to emerge, unauthorized landfills appeared, which polluted the air and water. Marginalization, alcoholism and other negative phenomena spread among the working population. Many families were forced to go abroad to earn for a living by low-skilled labor. The improving of SCs, provides good health care, safe and healthy housing, high quality education for all community residents; the support for public security and law and order; strengthening of the community spirit, its cohesion, which gives rise to the sense of belonging to a certain territory, that is the development of local identity, the promotion of creative development, the preservation of traditions, etc. Understanding this, SGTs, within the framework of the approved development strategy, will renovate and establish youth and leisure centers, homes for the elderly, will provide ongoing communication channels between the authorities and the community, will develop and improve the existing service sector.

\section{Information Links (ILs) of SGTs}

The purpose and main tasks of the system of information interaction between the authorities and the SGTs is to support one of the most important tasks of the local self-government system, namely: ensuring the transparency of government, the effective provision of the dialogue between the authorities and the community, and promoting the involvement of the community into local development.

The main directions of the state information policy are determined by the Law of Ukraine "On Information". The Law of Ukraine "On the Procedure for Reporting the Activity of State Bodies and Local Self-Government Bodies in Ukraine by the Mass Media" specifies the procedure for comprehensive and objective coverage of the activities of state authorities and local self-government bodies by the mass media (print media, television and radio). The Law of Ukraine "On Citizens Appeal" aims at improving the work of state authorities and local self-government.

In the process of IC development, it is important to increase the communicative competence of the SGTs. In order to acquire the communicative knowledge and skills necessary for effective communication, a system of activities should be established, which includes the organization of trainings, seminars for the active members of the community and youth on the development of the communicative competence, the ability to express their opinions, to hold discussions, debates, business negotiations, presentations, conflict management, and more. SGTs should be prepared for the discussions of ideas, perspectives, development, ways of solving urgent problems and community goals. The topics on created SGTs sites, Facebook pages should be interesting and encourage readers to dream, share ideas, and collaborate.

It is necessary to ensure a high level of awareness of the population about the real situation in the community, causation of problems and possibilities of their solution. The process of social mobilization can only be started when the majority of the population is informed about the situation in the community.

\section{Administrative connections of SGTs}

The institutional weakness of the district administration system and the very small, incompetent local governments have become one of the causes of the long depression of the self- 
governing territories. The extreme dependence on the centralized budgeting, lack of real authority by village councils have led to the fact that almost all state support programs proved to be ineffective and did not have significant implementation results for the community development. The existing legal norms and mechanisms of local democracy remained outside the management practice of local self-government bodies. Currently, the existing territorial organization and local self-government system has several disadvantages that significantly affect the effectiveness of administrative activity:

1. The regional and local level of governance has developed in accordance with the system of administrative and territorial structure of Ukraine, which was introduced in the early 1930s of the 20th century, in the interests of a centralized partybureaucratic administration. In connection with this, a considerable part of self-governing territorial units (in particular villages, settlements, towns of district importance) is deprived of the necessary financial and economic resources today.

2. The constitutional definition of the subject of local self-government - territorial community - is not consistent with the system of administrative and territorial units: other settlements are located within the administrative boundaries of some settlements; the territorial communities of which act in accordance with the Constitution of Ukraine as an independent subject of local self-government.

3. At the regional and district levels of government, where both executive and local self-government bodies (that are two centers of public authorities) function simultaneously, the lack of a proper legal frameworkfor the separation of powers of these bodies creates a danger of competing their competence.

4. An adequate financial and economic base of local self-government bodies has not been established to enable them to provide full public services.

The regional, sub-regional and local levels of government have the following connections: moral, psychological, social, synergistic and integrated.

\section{Moral connections of SGTs}

The specific problems of moral character, the solution of which requires an ethical culture, arise in the sphere of public administration. We need to initiate the changes in the relationship between the local government and the local community, the application of democratic leadership methods, the introduction of new population involvement practices, the increasing of the residents' activity, the transparent dialogue and partnerships in local budget planning, the provision of quality public services and more. In Ukraine, the search for an optimal model of ethical principles of democratic governance is continuing. The key guides in such a search are self-esteem, critical thinking, commitment to the democratic values, political education and competence, knowledge and compliance with laws, tolerance and willingness to compromise, participation in common affairs, and more. The core components are patriotism, law-abidingness and loyalty. Coupled with virtues such as social responsibility, public trust and community service, they serve as a moral duty, the performance of which demonstrates the high level of moral maturity of a civil servant personality and reveals a measure of the relation between public and personal interests, their combination and interconnection.

\section{Psychological connections at the SGTs level, identity}

Psychological interconnection and community feeling is a widely accepted concept of psychology of self-governing communities. This concept has a considerable potential in the view of the content of the current problems of Ukrainian SGTs: the low level of trust, as well as such concepts as weak social capital, social isolationism. Also, these psychological relationships are directly implicated in social identity, local / territorial identity, social interest and social feelings.

In Ukraine, the Soviet policy of denying our ethnicity had continued for a long time and denationalization had been implanted, which left its negative connotation in forming the consciousness of the Ukrainian people. To the current reform of local self-government, Ukraine was going by overcoming Soviet stereotypes, populism and the desire to make only visible changes, without changing anything in substance. The community in the sense of local community, habitat is a source of satisfaction of important social and psychological needs of the individual (belongingness and affection), by A. Maslow; existential needs for relatedness and rootedness in E. Fromm's terminology. It is in the local community that the topos of the real being of human are found, which determine the horizons of his/her rootedness, which are the existentials of the Home, the Field, the Temple (according to M. Heidegger) (Syla, 2013). 
It is obvious that each community has its own peculiarities in demographic, professional, educational, gender composition and so on. Therefore, there will be an emphasis on attracting people's potential. The key to effective collaboration is mutual trust and support in the community, a sense of being involved in a coherent whole, and an awareness of our common purpose. The concept of community is of particular relevance in Ukraine, which declares its progress towards civil society, improving the quality of life and social well-being.

\section{Local social connections of SGTs}

Social connection is a social action that expresses the dependence and compatibility of a self-governing territory. Social links are objective, dependent on the social conditions, in which communities are created and developed. The daily practice of life of Ukrainian communities shows that an important prerequisite for sustainable community development is the active participation of its members in the formation and direct implementation of local social policy. Cohesion of the community around the solution of the problem is the key to avoiding internal contradictions, which only facilitates its effective resolution. Therefore, the search and implementation of various forms of direct community involvement in local self-government can greatly contribute to the development of local communities. One form of community participation in local government is social mobilization, an ancient tool for mobilizing people for a particular social, political, religious, and other purpose.

In our opinion, it is currently important to study, improve and implement social mobilization among different segments of the population, which will stimulate not only the development of communities, but also raising the awareness of the population, which is the key to sustainable development. The mobilization process itself serves as a mechanism for involving public opinion and citizens in the decision-making process, which in the course of development will promote not only regionally (Makhnacheva, 2016).

\section{Synergistic / Integrated PT}

Connections of local development practices in advanced countries have accumulated "the material" to use the best practices of organizing, developing, managing and implementing planning policies for local development strategies, programs and projects. The key principles, on which synergies are based, that should be taken into account when planning and integrated community development and implementation of any local development initiatives, include: applying a systematic, holistic and integrated approach to local development, local leadership and vision, creativity, community involvement and collaboration, the need to move from closed local social systems to open global ones. Local development must be directed towards achieving strategic goals, but at the same time it must show some positive effect in the short term and be a proactive, flexible and adaptive process. Local development programs and activities should be transparent and accountable. Transparency and accountability make a significant contribution to ensuring the effectiveness of local economic development initiatives. The increasing competitiveness is an important component of local community planning activities (Vasylchenko, Parasiuk, Yeremenko, 2015).

\section{Conclusions}

It was determined that in the proposed model of SGTs development, the political, economic, environmental, social, informational and administrative types of relations are functioning at the state administrative level; and psychological, social, synergistic and integrated types of relationships are functioning at the regional, subregional and local levels respectively. Each of the types of relationships described above is based on a specific legal basis, but in the process of implementing decentralization reform and ensuring the development of SGTs, they all undoubtedly need some improvement.

\section{References:}

Andrienko, M. V., \& Shako, V. S. (2017). Mekhanizmy diyalnosti ekolohichnoyi polityky na rehionalnomu rivni [Mechanisms of implementation of state environmental policy at the regional level]. Derzhavne upravlinnya. Investytsiyi: praktyka ta informatsiya [State Administration. Investments: Practice and Experience] (electronic journal), no. 18, pp. 47-53. Retrieved from: http://www.investplan.com.ua/ pdf/18_2017/11.pdf (accessed February 24, 2020).

Babak, A. (2019). Obyednannya hromad maye pidvyshchyty yikh spromozhnist do rozvytku [Community integration should increase their capacity for development]. Uryadovyy portal [Government portal]. 
Retrieved from: https://www.kmu.gov.ua/news/obyednannya-gromad-maye-pidvishchiti-yihspromozhnist-do-rozvitku-alona-babak (accessed February 24, 2020).

Bryl, M., Vrublevsky, O., Dancheva, O., Seitosmanov, A., \& Chubarov, E. (2018). Uspishna terytorial'na hromada: buduyemo razom [Successful Territorial Community: Building Together]. Kharkiv: Factor Publishing House. Retrieved from: http://despro.org.ua/library/publication/UspishnaTerytorialna Hromada2018.pdf (accessed February 24, 2020).

International Alert (2017). Detsentralizatsiya $v$ Ukrayini dosyahnennya, nadiyi $i$ poboyuvannya [Decentralization in Ukraine of achievement, hope and fear] (electronic journal). Retrieved from: https://www.international-alert.org/sites/default/files/Ukraine_Decentralisation_UK_2017.pdf (accessed February 24, 2020).

Makhnacheva, N.M. (2016). Sotsial'na mobilizatsiya ta resursnyy potentsial hromady [Social mobilization and community resource potential]. Efektyvna ekonomika [Effective Economy], no. 10. Retrieved from: http://www.economy.nayka.com.ua/?op=1\&z=5175 (accessed February 24, 2020).

Official Bulletin of Ukraine (2015). Yevropeys'ka khartiya mistsevoho samovryaduvannya [European Charter of Local Self-Government], no. 24, p. 450, art. 718.

Pohorilko, V. F. (2001). Munitsypalne pravo Ukrayiny [Municipal Law of Ukraine]. Kiev: Jurincom Inter. (in Ukrainian)

Syla, T. I. (2013). Sotsial'na robota dlya staloho rozvytku: v poshukakh spil'nykh vektoriv [Social work for sustainable development: in search of common vectors]. Problemy sotsial'noyi roboty [Problems of social work], no. 2(3), pp. 74-84.

Vasylchenko, G., Parasiuk, I., \& Yeremenko, N. (2015). Planuvannya rozvytku terytorial'nykh hromad [The planning for the development of territorial communities]. Kyiv: "VNA enterprise". (in Ukrainian) 